\title{
PENGEMBANGAN ALAT UKUR KUALITAS HIDUP INDONESIA
}

\author{
Latifa Resmiya, Ifa H. Misbach
}

Departemen Psikologi, Fakultas Ilmu Pendidikan, Universitas Pendidikan Indonesia

E-mail:latifaresmiya@gmail.com, ifahmisbach@gmail.com

\begin{abstract}
This research aimed to develop a Kualitas hidup measurement tool in Indonesia. The research method used in this study is a combined method of qualitative and quantitative research (mixed method). The qualitative stage aimed at exploring the theme of kualitas hidup totaling 250 people. Meanwhile, participants in the quantitative stage aimed at identifying psychometric properties (validity and reliability) numbered 759 people. The data analysis technique used for qualitative data is open coding. Quantitative data consists of construct validity test using factorial validity with exploratory factor analysis (EFA), convergent validity, and known-group validity, and estimation of internal consistency reliability using Cronbach's Alpha. The EFA results show that the Kualitas hidup Indonesia measuring instrument consists of 9 factors and 30 items with a very high reliability coefficient $(\alpha=0.88)$. Convergent validity in this study was carried out by correlating the Kualitas hidup Indonesia measuring tool with the WHOQOL-BREF measurement tool. Validity by known-group is done by comparing demographic data of age, sex, marital status, education level, employment status, and health conditions using One-Way ANOVA.
\end{abstract}

Key words: Quality of life, factor analysis, convergent validity, known-group validity, reliability

\begin{abstract}
Abstrak
Penelitian ini bertujuan untuk mengembangkan alat ukur Kualitas Hidup di Indonesia. Metode penelitian yang digunakan dalam penelitian ini adalah metode campuran penelitian kualitatif dan kuantitatif. Partisipan pada tahap kualitatif yang bertujuan untuk mengeksplorasi tema kualitas hidup berjumlah 250 orang. Sedangkan, partisipan pada tahap kuantitatif yang bertujuan untuk mengidentifikasi properti psikometri (validitas dan reliabilitas) berjumlah 759 orang. Teknik analisis data yang digunakan untuk data kualitatif adalah open coding. Sementara itu, untuk data kuantitatif terdiri dari uji validitas konstruk menggunakan validitas faktorial dengan analisis faktor eksploratori (EFA), validitas konvergen, dan validitas by known-group, serta estimasi reliabilitas konsistensi internal dengan menggunakan Alpha Cronbach. Hasil EFA menunjukkan bahwa alat ukur Kualitas Hidup Indonesia (KHI) terdiri dari 9 faktor dan 30 aitem dengan koefisien reliabilitas sangat tinggi $(\alpha=0.88)$. Kualitas Hidup Indonesia berkorelasi cukup kuat dengan WHOQOL-BREF dan juga menunjukkan ada perbedaan kualitas hidup antar usia, status pernikahan, tingkat pendidikan, status pekerjaan, dan kondisi kesehatan, serta tidak ada perbedaan pada jenis kelamin.
\end{abstract}

Kata kunci: Kualitas hidup, analisis faktor eksploratori, validitas konvergen, validitas by known-group, reliabilitas 


\section{PENDAHULUAN}

Kualitas hidup sudah menjadi isu utama di banyak negara saat ini (Molnar, 2009), tidak terkecuali di Indonesia. Indonesia adalah negara berkembang dengan agenda pembangunan berkelanjutan. Pembangunan berkelanjutan yang dimaksud adalah konsep meningkatnya popularitas yang bertujuan untuk menghasilkan kesejahteraan menyeluruh dalam jangka panjang melalui penggunaan dan pengelolaan sumber daya alam dan ekonomi yang bijak, dan melalui penghormatan terhadap manusia dan makhluk hidup lainnya (Grizans, 2009). Kesejahteraan tersebut mengacu pada kesejahteraan anggota masyarakat, dan kesejahteraan sendiri dapat diukur melalui indeks kualitas hidup (Appulembang \& Dewi, 2017).

Kualitas hidup atau kualitas hidup merupakan tingkat kesejahteraan yang dirasakan oleh individu atau sekelompok orang (Molnar, 2009). Kualitas hidup adalah konsep multidimensional yang kompleks (RADF, 2009). Kualitas hidup dapat tampak sebagai keadaan kesehatan, fungsi fisik, status kesehatan yang dirasakan, kesehatan subjektif, persepsi mengenai kesehatan, simptom, kepuasan kebutuhan, kognisi individu, ketidakmampuan fungsional, gangguan kejiwaan, kesejahteraan dan terkadang dapat bermakna lebih dari satu pada waktu yang bersamaan (Hunt, 1997). Terdapat tiga pendekatan terhadap konsep kualitas hidup, yaitu (1) menyamakan kualitas hidup dengan kesehatan, (2) menyamakan dengan well-being (kesejahteraan), dan (3) menganggap kualitas hidup sebagai superordinate construct (konstruk yang bersifat global) (Post, Witter, \& Schrijvers, 1999; Sekarwiri, 2008).

Dalam penelitian mengenai kesehatan, kualitas hidup sering disamakan dengan kesehatan, yang kemudian menggunakan istilah yang lebih sempit, yaitu 'healthrelated kualitas hidup' atau 'health status' (Post, Witter, \& Schrijvers, 1999). Pada pendekatan yang kedua, kualitas hidup disamakan dengan well-being (kesejahteraan) dan dilihat sebagai penilaian atau evaluasi subjektif secara keseluruhan dari kehidupan seseorang, yang sepadan dengan konsep seperti global well-being (kesejahteraan umum), subjective well-being (kesejahteraan subjektif) atau happiness (kebahagiaan) (Post, Witter, \& Schrijvers, 1999). Kualitas hidup umum adalah fungsi dari kepentingan kebutuhan responden atau kelompok dalam hal kontribusi relatif terhadap kesejahteraan subyektif (Costanza, dkk., 2010).

Pendekatan yang selanjutnya adalah melihat kualitas hidup sebagai konstruk yang bersifat global (superordinate construct). Pendekatan kualitas hidup tersebut mencakup kesehatan dan kesejahteraan dalam definisi kualitas hidup yang lebih luas (Post, Witter, \& Schrijvers, 1999). Definisi kualitas hidup yang lebih luas juga diungkapkan oleh WHO (World Health Organization). WHO mendefinisikan kualitas hidup sebagai konsep yang subjektif dan menekankan pada persepsi individu mengenai kehidupannya saat ini dan persepsi individu tersebut dapat dipengaruhi oleh budaya dan sistem nilai dimana individu tinggal, dan berhubungan 
dengan tujuan, harapan, standar serta kepentingan mereka (WHOQOL Group, 1998a). Oleh sebab itu, kualitas hidup dapat didefinisikan sebagai penilaian pribadi individu mengenai aspek-aspek penting dalam kehidupannya saat ini.

Penelitian mengenai kualitas hidup semakin berkembang dalam tiga dekade terakhir. Dalam situs springerexemplar.com (diakses pada 12 November 2017), pencarian komputer dengan kata kunci "kualitas hidup" menunjukkan hasil 171.744 artikel. WHO sendiri melakukan serangkaian penelitian mengenai kualitas hidup dengan menginisiasi sebuah proyek kolaborasi internasional yang khusus mengembangkan alat ukur kualitas hidup, atau yang disebut dengan WHOQOL (World Health Organization Kualitas hidup) (WHOQOL Group, 1995). WHOQOL adalah sebuah kolaborasi internasional yang telah berlangsung selama beberapa tahun untuk mengembangkan penilaian kualitas hidup yang dapat diandalkan, valid, dan responsif yang berlaku di seluruh budaya (WHOQOL Group, 1995).

Kualitas hidup diusulkan sebagai konsep multiskala, multidimensi yang berisi interaksi elemen objektif dan subyektif (Costanza, dkk., 2010). Berbagai alat ukur mengenai kualitas hidup telah dipublikasikan oleh para peneliti, seperti alat ukur SF36 (Ware \& Sherbourne, 1992), EQ-5D (EuroQol Group, 2017), WHOQOL-100 \& WHOQOL-BREF (WHOQOL Group, 1998b). WHOQOL-BREF sendiri telah terbukti valid dan reliabel untuk mengukur kualitas hidup yang terdiri 26 item dan 4 domain (kesehatan fisik, psikologis, hubungan sosial, serta lingkungan) (Salim, dkk., 2007). WHOQOL-BREF juga telah diteliti dan dikembangkan oleh sejumlah peneliti dari berbagai negara, seperti Iran (Vahedi, 2010), Perancis (Baumann, dkk., 2010), India (Mudey, dkk., 2011), Tiongkok (Xia, dkk., 2012), dan tidak terkecuali Indonesia (Salim, dkk., 2007).

Walaupun alat ukur-alat ukur kualitas hidup yang dikembangkan oleh peneliti Barat tersebut telah dinyatakan valid dan reliabel untuk mengukur kualitas hidup, tetapi domain atau aspek yang terdapat di dalamnya belum tentu mewakili aspekaspek kualitas hidup masyarakat Indonesia. Moons, dkk. (2004) menyatakan bahwa pengukuran kualitas hidup yang terstandardisasi mungkin tidak relevan bagi individu yang diukur kualitas hidupnya karena mengabaikan variasi dari persepsi individu mengenai aspek-aspek yang dianggap penting bagi kehidupannya. Pengukuran kualitas hidup yang terstandardisasi tidak disarankan dalam ruang lingkup negara Indonesia dikarenakan masih banyaknya masalah-masalah politik, sosial, ekonomi yang sedang dihadapi oleh masyarakatnya (Komardjaja \& Leisch dalam Nofitri, 2009).

Dalam menanggapi hal tersebut, indigenous psychology mengusulkan pendekatan dalam konteks konstruksi instrumen dan pengukuran atribut psikologi (Anggoro \& Widhiarso, 2010). Indigenous psychology merupakan kajian ilmiah mengenai perilaku dan mental manusia yang bersifat pribumi, tidak dibawa dari daerah lain, dan didesain untuk masyarakatnya sendiri (Kim \& Berry, 1993; Anggoro \& Widhiarso, 2010). Dengan menggunakan pendekatan indigenous, sebuah penelitian 
dapat menekankan pada perilaku dan cara berpikir seorang individu dalam konteks budayanya (Mujamiasih, 2013).

Budaya memiliki dampak besar pada kualitas hidup, yang mana mungkin memiliki pengaruh positif atau negatif pada realisasi diri individu dalam suatu organisasi, masyarakat, atau negara tertentu (Molnar, 2009). Dalam studi yang dilakukan oleh Inoguchi \& Fujii (2013), yang berusaha mengidentifikasi faktorfaktor kualitas hidup secara keseluruhan di negara-negara Asia, dijelaskan bahwa terdapat perbedaan domain penentu yang memengaruhi kualitas hidup di suatu negara. Di Jepang, domain pasca-materialis, seperti pernikahan, persahabatan, kesehatan, kehidupan keluarga, kehidupan spiritual adalah penentu utama dan berhubungan positif dengan kualitas kehidupan secara keseluruhan (Inoguchi \& Fujii, 2013). Sedangkan di Indonesia, domain materialis, seperti standar hidup, pendidikan, pekerjaan, perumahan, dan pendapatan rumah tangga adalah penentu utama dan berhubungan positif dengan kualitas hidup (Inoguchi \& Fujii, 2013).

Budaya masyarakat Indonesia sendiri cenderung kolektif, yang menekankan tujuan kelompok dan keharmonisan, kohesi, serta kerja sama (Matsumoto, 1996), berbeda dengan budaya Barat yang cenderung individualis. Budaya Indonesia merupakan budaya yang majemuk yang terdiri dari budaya-budaya yang berada di Indonesia, seperti budaya Sunda, Jawa, Betawi, dan beragam budaya lainnya (Magnis-Suseno, 1996). Walaupun terdapat banyak budaya di Indonesia, tapi terdapat nilai-nilai utama bangsa Indonesia yang dominan, yaitu harmonis, toleransi, gotong-royong, dan religius (Sihombing \& Pongtuluran, 2013).

Di Indonesia sendiri, pengembangan alat tes psikologi yang handal dan terpercaya serta sesuai dengan kebutuhan di Indonesia masih terhambat karena upaya yang diberikan untuk mengembangkan alat tes tersebut pun sedikit (Suwartono, 2016). Di samping itu, belum terdapat kesepakatan bersama di antara para peneliti mengenai definisi kualitas hidup dan hal tersebut tercermin dalam pilihan item alat ukur para peneliti (Skevington, dkk., 2004). Salah satu penelitian pengembangan alat ukur kualitas hidup di Indonesia dilakukan oleh Appulembang \& Dewi (2017) dan menghasilkan alat ukur Quality of Life Urban Community yang khusus untuk populasi masyarakat perkotaan. Alat ukur tersebut merupakan pengembangan dari survei Rural Alberta's Development Fund (RADF, 2009) mengenai kualitas hidup, kemampuan suatu komunitas, pelayanan kesehatan dan kesempatan pendidikan pelatihan. Selain itu, terdapat juga pengembangan alat ukur kualitas hidup nelayan di Karawang yang dilakukan oleh Laratmase (2016).

Sejauh yang peneliti ketahui, selain WHOCOL, alat ukur mengenai kualitas hidup yang dikembangkan dan disesuaikan dengan kebutuhan di Indonesia belum cukup banyak. Atas dasar tersebut, alat ukur kualitas hidup yang sesuai dengan nilainilai serta budaya Indonesia perlu dikembangkan. Pengembangan alat ukur kualitas hidup tersebut dapat membantu para peneliti untuk mengukur kualitas hidup di Indonesia secara lebih akurat, yang nantinya dapat digunakan oleh pihak-pihak 
terkait untuk mengambil kebijakan terkait kesejahteraan masyarakat di Indonesia. Oleh karena itu, peneliti melakukan studi awal mengenai pengembangan alat ukur kualitas hidup di Indonesia.

\section{METODE}

\section{Desain Penelitian}

Penelitian ini menggunakan metode campuran. Metode campuran adalah gabungan penelitian kuantitatif dan kualitatif dalam sebuah studi penelitian (Creswell, 2014). Penelitian kualitatif menggunakan teknik pengumpulan data open ended questionaire dan bertujuan untuk mengeksplorasi tema kualitas hidup. Sedangkan, penelitian kuantitatif digunakan untuk mengidentifikasi properti psikometri (validitas dan reliabilitas) instrumen yang telah dikonstruksi peneliti berdasarkan data kualitatif yang diperoleh. Pada tahap kualitatif, teknik analisis data yang digunakan adalah open coding. Sedangkan pada tahap kuantitatif, teknik analisis data yang digunakan terdiri dari uji validitas konstruk menggunakan validitas faktorial dengan analisis faktor eksploratori (EFA), validitas konvergen, dan validitas by known-group, serta estimasi reliabilitas konsistensi internal dengan menggunakan Alpha Cronbach.

\section{Partisipan}

Pengambilan sampel dalam penelitian ini menggunakan teknik nonprobability sampling dengan convenience sampling, di mana anggota populasi yang memenuhi kriteria tertentu, seperti kemudahan akses, kedekatan geografis, ketersediaan pada waktu tertentu, atau kesediaan untuk berpartisipasi dalam penelitian (Dörnyei, 2007). Peneliti mengambil sampel masyarakat umum berusia dewasa (lebih dari 18 tahun) dengan latar belakang yang heterogen. Kedekatan geografis dan akses dengan domisili peneliti menyebabkan sampel penelitian ini mayoritas berasal dari suku Sunda. Pengambilan sampel dalam penelitian ini terdiri dari dua tahap. Sampel dalam penelitian tahap kualitatif berjumlah 250 orang. Sedangkan, pada tahap kuantitatif sampel berjumlah 759 orang. Kuantitas sampel ini termasuk dalam kategori very good untuk dilakukan analisis faktor menurut kriteria rule of thumb dari Comrey \& Lee (1992); Van Voorhis \& Morgan (2007).

\section{HASIL}

Tahap kualitatif pada pengembangan alat ukur kualitas hidup adalah eksplorasi tema kualitas hidup yang akan digunakan dalam penyusunan item. Metode pengam- 
bilan data eksplorasi menggunakan open-ended questionaire yang dianalisis menggunakan teknik open coding dengan mengkategorikan respon berdasarkan kata kunci, similaritas dan maknanya (Anggoro \& Widhiarso, 2010; Oktapialdi, 2018). Eksplorasi tema menghasilkan 44 tema dengan frekuensi terbanyak dan 11 tema khas, yang jarang ditemui dalam literatur lain mengenai kualitas hidup, yang kemudian dikembangkan menjadi item dalam alat ukur. Selanjutnya adalah konstruksi alat ukur atau pembuatan item dari hasil tema-tema pada tahap kualitatif. Bentuk skala yang digunakan adalah tipe Likert, dengan lima pilihan jawaban, Sangat Sesuai, Sesuai, Netral, Tidak Sesuai, dan Sangat Tidak Sesuai. Prosedur selanjutnya adalah penulisan item yang didasarkan pada tema yang menghasilkan 78 butir yang didasarkan juga dari hasil expert judgement.

Pada tahap kuantitatif, peneliti melakukan identifikasi properti psikometris dengan melihat validitas konstruk dan reliabilitas alat ukur yang telah dikonstruksi. Analisis validitas konstruk yang dilakukan dalam penelitian ini menggunakan pendekatan analisis faktor atau validitas faktorial, validitas konvergen, dan validitas by known group. Hasil Analsis Faktor nilai KMO sebesar 0,914 dan nilai Bartlett's Test sebesar 3003 dengan signifikansi 0,000. Hal tersebut menunjukkan bahwa variabel layak untuk dianalisis faktor. Dilakukan analisis faktor dengan memilih item yang memiliki korelasi item-total $\geq 0,30$ yaitu terdiri dari 9 faktor dan 30 item.

Berdasarkan EFA, dimensi Kualitas Hidup Indonesia adalah sebagai berikut:

1. Keagamaan \& Spiritualitas, merupakan penghayatan individu terhadap hubungannya dengan Tuhan.

2. Pemaknaan Hidup, merupakan penghayatan individu mengenai arti kehidupannya.

3. Pencapaian Hidup, merupakan persepsi individu terhadap apa yang diinginkannya dalam hidup.

4. Etos Kerja, merupakan ukuran kinerja individu yang ditandai dengan tanggung jawab, manajemen waktu, kesungguhan dalam bekerja.

5. Pendidikan \& Ilmu Pengetahuan, merupakan pemaknaan individu terhadap apa yang dipelajarinya.

6. Prososial, merupakan tindakan yang dilakukan individu untuk membantu orang lain.

7. Hubungan Sosial

Hubungan sosial merupakan interaksi dan kedekatan individu dengan orang lain.

8. Kesehatan Fisik, merupakan penghayatan individu terhadap kondisi tubuhnya.

9. Psikologis, merupakan proses mental yang memengaruhi perilaku individu.

Validitas konvergen pada penelitian ini adalah melakukan korelasi antara Kualitas hidup Indonesia dengan WHOQOL-BREF (WHOQOL Group, 1998b). Validitas alat ukur Kualitas Hidup Indonesia (KHI) mempunyai korelasi atau hubungan yang cukup kuat yaitu 0,734. Selain itu korelasi antar faktor Kualitas 
Hidup Indonesia (KHI) \& WHOQOL-BREF memiliki rentang korelasi antara 0,147 sampai 0,750 .

Dari faktor atau dimensi Kualitas Hidup Indonesia, dimensi pemaknaan hidup adalah dimensi yang memiliki rata-rata korelasi tertinggi dengan dimensi-dimensi WHOCOL-BREF yaitu 0,586, yang disusul oleh dimensi Psikologis yaitu 0,429. Sementara itu, dimensi Psikologis dalam WHOCOL-BREF adalah dimensi yang paling tinggi rata-rata korelasinya dengan dimensi-dimensi dalam Kualitas Hidup Indonesia (KHI) yaitu 0,429 yang berarti sama besarnya dengan dimensi psikologis dalam WHOCOL-BREF.

Tabel 1

Korelasi Dimensi Kualitas Hidup Indonesia \& WHOQOL-BREF

\begin{tabular}{|c|c|c|c|c|c|c|}
\hline \multirow{2}{*}{\multicolumn{2}{|c|}{ Alat Ukur }} & \multicolumn{4}{|c|}{ WHOQOL-BREF } & \multirow{3}{*}{$\begin{array}{c}\text { Rata-Rata } \\
\text { Korelasi } \\
\end{array}$} \\
\hline & & \multirow{2}{*}{$\begin{array}{c}\begin{array}{c}\text { Kesehatan } \\
\text { Fisik }\end{array} \\
0,310\end{array}$} & \multirow{2}{*}{$\begin{array}{c}\text { Psikologis } \\
0,354\end{array}$} & \multirow{2}{*}{$\begin{array}{c}\begin{array}{c}\text { Hubungan } \\
\text { Sosial }\end{array} \\
0,277\end{array}$} & \multirow{2}{*}{$\begin{array}{c}\text { Lingkungan } \\
0,282\end{array}$} & \\
\hline \multirow{12}{*}{ 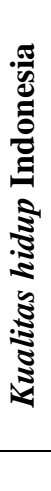 } & Keagamaan \& & & & & & \\
\hline & Spiritualitas & & & & & \\
\hline & Pemaknaan Hidup & 0,543 & 0,750 & 0,559 & 0,493 & 0,586 \\
\hline & Pencapaian Hidup & 0,330 & 0,507 & 0,409 & 0,324 & 0,393 \\
\hline & Etos Kerja & 0,326 & 0,363 & 0,207 & 0,220 & 0,279 \\
\hline & Pendidikan \& Ilmu & 0,329 & 0,339 & 0,309 & 0,307 & 0,321 \\
\hline & Pengetahuan & & & & & \\
\hline & Prososial & 0,163 & 0,229 & 0,134 & 0,147 & 0,168 \\
\hline & Hubungan Sosial & 0,390 & 0,366 & 0,443 & 0,299 & 0,375 \\
\hline & Kesehatan Fisik & 0,418 & 0,427 & 0,342 & 0,358 & 0,386 \\
\hline & Psikologis & 0,435 & 0,528 & 0,382 & 0,370 & 0,429 \\
\hline & Rata-Rata Korelasi & 0,36 & 0,429 & 0,34 & 0,311 & 0,36 \\
\hline
\end{tabular}

Faktor Pencapaian Hidup memiliki korelasi yang cukup kuat dengan domain Psikologis WHOCOL-BREF $(\mathrm{r}=0,507)$, berbeda dengan domain lainnya yang memiliki korelasi yang tidak terlalu kuat $(\mathrm{r}<0,5)$. Faktor Etos Kerja, Pendidikan \& Ilmu Pengetahuan, dan Prososial, secara keseluruhan faktor-faktor tersebut memiliki korelasi yang tidak cukup kuat $(\mathrm{r}<0,5)$ dengan setiap domain dalam alat ukur WHOQOL-BREF. Faktor Hubungan Sosial dalam Kualitas Hidup Indonesia juga memiliki korelasi yang tidak terlalu kuat $(r=0,443)$ dengan domain Hubungan Sosial WHOQOL-BREF. Faktor Kesehatan Fisik dalam alat ukur Kualitas Hidup Indonesia memiliki korelasi yang tidak terlalu kuat $(\mathrm{r}=0,418)$ dengan domain Kesehatan Fisik maupun domain lainnya dalam alat ukur WHOQOL-BREF. Sementara itu, faktor Psikologis memiliki korelasi yang cukup kuat $(\mathrm{r}=0,528)$ dengan domain Psikologis dalam alat ukur WHOQOL-BREF. Sedangkan dengan domain lain dalam alat ukur WHOQOL-BREF, faktor Psikologis memiliki korelasi yang tidak terlalu kuat $(\mathrm{r}<0,5)$. Reliabilitas Alpha Kualitas Hidup Indonesia yang sangat tinggi $(0,88)$ yang relatif setara dengan reliabilitas WHOQOL-BREF $(0,89)$. 


\section{PEMBAHASAN}

Hasil umum penelitian ini menunjukkan bahwa Kualitas Hidup Indonesia (KHI) memiliki reliabilitas tinggi setinggi WHOQOL BREF. Selain itu KHI menghasilkan sembilan dimensi yang semuanya berkorelasi positif dengan dimensi-dimensi WHOCOL-BREF. Di sisi lain, perbandingan KHI berdasarkan demografis, usia, jenis kelamin, status pernikahan, tingkat pendidikan, status pekerjaan, dan kondisi kesehatan berkesesuaian dengan penelitian-penelitian sebelumnya tentang kualitas hidup. Misalnya, kualitas hidup orang dengan usia diatas 51 memiliki kualitas hidup yang paling tinggi yang sebelumnya juga ditemukan oleh Susilawati (2016) yang menemukan bahwa kualitas hidup seseorang yang berusia di bawah 50 tahun cenderung lebih rendah dibandingkan seseorang yang berusia di atas 50 tahun. Di samping itu, Moons, dkk. (2004) menyatakan bahwa usia adalah salah satu faktor yang mempengaruhi kualitas hidup.

Laki-laki dan perempuan memiliki kualitas hidup yang tidak berbeda. Hasil ini sesuai penelitian Appulembang \& Dewi (2017) yang menemukan tidak terdapat perbedaan antara kualitas hidup laki-laki dan perempuan. Demikian juga dengan status pernikahan, dimana orang yang menikah memiliki kualitas hidup yang lebih baik daripada tidak menikah. Susilawati (2016) juga menemukan bahwa seseorang yang belum/tidak menikah cenderung memiliki kualitas hidup yang lebih rendah dibandingkan dengan seseorang yang sudah menikah.

Selain itu, tingkat pendidikan, status pekerjaan, dan kesehatan juga menunjukkan hasil yang berbeda dengan penelitian lain. Semakin rendah pendidikan akan semakin rendah kualitas hidup orang. Hasil tersebut mendukung penelitian Wahl, dkk (2004) yang menemukan bahwa kualitas hidup seseorang akan meningkat seiring dengan lebih tingginya tingkat pendidikan orang tersebut. Moons, dkk. (2004) juga menyatakan bahwa tingkat pendidikan adalah salah satu faktor yang dapat mempengaruhi kualitas hidup secara subjektif. Demikian juga orang yang memiliki pekerjaan akan memiliki kualitas yang lebih tinggi daripada yang tidak memiliki pekerjaan. Wahl, dkk. (2004) juga menemukan bahwa kualitas hidup orang yang belum bekerja lebih rendah dibandingkan orang yang sudah bekerja. Terakhir, partisipan yang sedang dalam kondisi tidak sakit memiliki nilai rata-rata yang lebih tinggi, dibandingkan partisipan yang sedang dalam kondisi sakit. Penelitian Wahl, dkk. (2004) menyatakan bahwa seseorang yang memiliki penyakit atau masalah kesehatan jangka panjang memiliki kualitas hidup yang lebih rendah daripada dengan yang tidak memiliki masalah kesehatan.

KHI memiliki reliabilitas Alpha 0,88 yang relatif setara dengan WHOQOLBREF yaitu 0,89 . Koefisien reliabilitas setiap domain WHOQOL-BREF berkisar antara 0,64-0,79, sedangkan reliabilitas setiap faktor KHI antara 0,57-0,87. Reliabilitas faktor-faktor KHI yang paling tinggi adalah faktor Pemaknaan Hidup, yaitu 0,87, sedangkan reliabilitas paling rendah adalah faktor Psikologis, yaitu sebesar 0,57 . 


\section{DAFTAR PUSTAKA}

Anggoro, Wahyu J., \& Widhiarso, Wahyu. (2010). Konstruksi dan Identifikasi Properti Psikometris Instrumen Pengukuran Kebahagiaan Berbasis Pendekatan Indigenous Psychology: Studi Multitrait-Multimethod. Jurnal Psikologi, Vol. 37, No. 2, 176-178.

Appulembang, Y. A., \& Dewi. F. (2017). Pengembangan Alat Ukur Kualitas hidup Urban Community. Jurnal Muara Ilmu Sosial, Humaniora, dan Seni, Vol. 1, No. 1, April 2017: hlm 272-277.

Comrey, A. L., \& Lee, H. B. (1992). A first course in factor analysis (2nd ed.). Hillsdale, NJ: Erlbaum.

Costanza, R., dkk. (2010). An Integrative Approach to Kualitas hidup Measurement, Research, and Policy. S.A.P.I.EN.S [Online], 1.1, connection on 13 December 2017.

Costello, A. B., \& Osborne, J. W. (2005). Best practices in exploratory factor analysis: Four recommendations for getting the most from your analysis. Practical Assessment, Research \& Evaluation, 10, 1-9.

Creswell, J. W. (2014). Research Design Qualitative, Quantitative and Mixed Methods Approaches (4th ed.). Thousand Oaks, CA Sage.

Dörnyei, Z. (2007). Research methods in applied linguistics. New York: Oxford University Press.

EuroQol Group. (2017, April 28th). EQ-5D Instruments. Retrieved December 13th, 2017, from EQ-5D: https://euroqol.org/eq-5d-instruments.

Floyd, F. J., \& Widaman, K. F. (1995). Factor analysis in the development and refinement of clinical assessment instruments. Psychological Assessment, 7, 286299. doi:10.1037/1040-3590.7.3.286.

Grizans, J. (2009). Urban Issues and Solutions in the Context of Sustainable Development: A review of the literature. Department of Environmental and Business Economics, University of Southern Denmark.

Harman, H. H. (1976). Modern factor analysis (3rd ed. revised). Chicago, IL: University of Chicago Press.

Hunt, S. M. (1997). Editorial: The Problem of Kualitas hidup. Kualitas hidup Research, 6(3), 205-212.

Ihsan, H. (2013). Metode Skala Psikologi. Bandung: Tidak diterbitkan.

Inoguchi, Takashi, \& Fujii, Seiji. (2013). Kualitas hidup in Asia; A Comparison of Kualitas hidup in 29 Asian Societies, Springer. 
Kim, Uichol, \& Berry, John. (1993). Indigenous psychologies: Research and experience in cultural context. Cross-cultural research and methodology series, Vol. 17.

Laratmase, A. J. (2016). Pengembangan Alat Ukur Kualitas Hidup Nelayan: Suatu Studi Analisis Faktor dalam rangka Uji Validitas Konstruk di Karawang. Jurnal Pendidikan Lingkungan dan Pembangunan Berkelanjutan, Vol. 17 No. 01.

Magnis-Suseno, F. (1996). Budaya dan pengaruhnya terhadap budaya perusahaan Indonesia. Usahawan, No. 7, Juli.

Manning, Steven, G. (2015). The Development and Validation of A Measure of Disengagement. Thesis: Department of Psychology, Colorado State University.

Matsumoto, D. (1996). Culture and Psychology. Brook/Cole Publishing Company: Washington.

Moons, Philip., \& dkk. (2004). Validity, reliability and responsiveness of the "Schedule for the Evaluation of Individual Kualitas hidup - Direct Weighting" (SEIQoL-DW) in congenital heart disease. Health and Kualitas hidup Outcomes, 2: 27.

Molnar, P. (2009). Some Aspects of The Measurement and Improvement of Kualitas hidup. Diambil dari https://www.scribd.com/document/10203667/ SomeAspects-of-the-Measurement-and-Improvement-of-Quality-of-Life?from_email_ 04 _friend_send $=1$.

Mudey, A., dkk. (2011). Assessment of Kualitas hidup among Rural and Urban Elderly Population of Wardha District, Maharashtra, India. Ethno Med, 5(2): 8993.

Mujamiasih, Murti. (2013). Subjective Well-Being (SWB): Studi Indigenous Pada PNS dan Karyawan Swasta yang Bersuku Jawa di Pulau Jawa. Skripsi: Universitas Negeri Semarang.

Nunnally, J. C., \& Bernstein, I. H. (1994). Psychometric theory. 3rd ed. New York: McGraw-Hill.

Oktapialdi, R. (2018). Pengembangan Skala Social Desirability. Skripsi: Departemen Psikologi, Universitas Pendidikan Indonesia.

Post, Marcel., Witter, Luc., \& Schrijvers, A.J.P. (1999). Kualitas hidup and the ICIDH: Towards an integrated conceptual model for rehabilitation outcomes research. Clinical rehabilitation. 13. 5-15. 10.1191/026921599701532072.

Raykov, T., \& Marcoulides, G. A. (2010). Introduction to Psychometric Theory. New York: Routledge. 
Rural Alberta Development Fund (RADF). (2009). Kualitas hidup and community capacity population survey: Baseline results. Howard Research and Management Consulting Inc. Retrieved from: www.radf.ca/uploads/ qualityoflifesurvey75714.pdf.

Salim, O. Ch., dkk. (2007). Validitas dan reliabilitas World Health Organization Kualitas hidup-BREF untuk mengukur kualitas hidup lanjut usia. Universa Medicina, Vo. 26, No. 1.

Sekarwiri, Edesia. (2008). Hubungan Antara Kualitas Hidup dan Sense of Community pada Warga DKI Jakarta yang tinggal di daerah Rawan Banjir. Skripsi: Fakultas Psikologi, Universitas Indonesia.

Sihombing, S. O., \& Pongtuluran, F. D. (2011). Pengidentifikasian Dimensi-dimensi Budaya Indonesia: Pengembangan Skala dan Validasi. Retrieved 11 November 2018 http://www.academia.edu/1975261/Paper_Pengidentifikasian_Dimensi_ Budaya_Indonesia_Pengambangan_Skala_dan_Validasi.

Skevington, S. M., dkk. (2004). The World Health Organization's WHOQOL-BREF kualitas hidup assessment: psychometric properties and results of the international field trial, a report from the WHOQOL Group. Qual Life Res; 13: 299-310.

Springer. (2017, November 12th). Retrieved November 12th, 2017, from springerexemplar.com: http://www.springerexemplar.com/search.aspx?q=\% 22quality $\% 20 \mathrm{of} \%$ 20life $\% 22 \&$ similar=false.

Sumintono, B., \& Widhiarso, W. (2014). Aplikasi Model Rasch untuk Penelitian Ilmu-Ilmu Sosial (Edisi Revisi). Cimahi: Trim Komunikata Publishing House.

Susilawati. (2016). Analisis Faktor-Faktor yang Berhubungan dengan Kualitas Hidup Klien Kanker Payudara di RSUP Dr. M. Djamil Padang. Tesis: Universitas Andalas.

Suwartono, C. (2016). Alat Tes Psikologi Konteks Indonesia: Tantangan Psikologi di Era MEA. Journal Psikologi Ulayat, Vol. 3 No. 1.

Vahedi, Shahrum. (2010). World Health Organization Quality-of-Life Scale (WHOQOL-BREF): Analyses of Their Item Response Theory Properties Based on the Graded Responses Model. Iran J. Psychiatry, 5:140:153.

Van Voorhis, C. R. W., \& Morgan, Betsy. (2007). Understanding Power and Rules of Thumb for Determining Sample Size. Tutorials in Quantitative Methods for Psychology, 3 (2) 43-50. 10.20982/tqmp.03.2.p043.

Wahl, Astrid K., \& dkk. (2004). Kualitas hidup in the general Norwegian population, measured by the Kualitas hidup Scale (QOLS-N). Kualitas hidup Research, 13: 1001-1009. 
Ware, J. E., \& Sherbourne, C. D. (1992). The MOS 36-item Short-Form Health Survey (SF-36). I: Conceptual framework and item selection. Med Care; 30: 473 $-483$.

WHOQOL Group. (1995). The World Health Organization Kualitas hidup Assessment (WHOQOL): Position Paper from the World Health Organization. Soc. Sci. Med. Vol. 41, No. 10, pp. 1403-1409.

WHOQOL Group. (1998a). The World Health Organization Kualitas hidup Assessment (WHOQOL): Development \& General Psychometric Properties. Soc. Sci. Med. Vol. 46, No. 12, pp. 1569-1585.

WHOQOL Group. (1998b). Development of the World Health Organization WHOQOL-BREF kualitas hidup assessment. Psychol Med; 28: 551-558.

Xia, Ping., \& dkk. (2012). Kualitas hidup of Chinese urban community residents: a psychometric study of the mainland Chinese version of the WHOQOL-BREF. BMC Medical Research Methodology, 12:37.

Yong, A. G., \& Pearce, Sean. (2013). A Beginner's Guide to Factor Analysis: Focusing on Exploratory Factor Analysis. Tutorials in Quantitative Methods for Psychology, Vo. 9 (2), p. 79-94. 